\title{
PEMANFAATAN MAKROZOOBENTOS SEBAGAI BIOINDIKATOR PENCEMARAN LOGAM Pb DAN Cd DI PERAIRAN TELUK SEMARANG
}

Utilization of Macrozoobentos as Bioindicator of Metal Pollution of Pb and Cd in Semarang Bay Waters

\author{
Irzzan Gaus, Haeruddin*), Churun Ain
}

Program Studi Manajemen Sumberdaya Perairan, Departemen Sumberdaya Akuatik

Fakultas Perikanan dan Ilmu kelautan, Universitas Diponegoro

Jl. Prof. Soedarto, SH, Tembalang, Semarang, Jawa Tengah - 50275. Telp/Fax. +6224 7474698

Email: irzan360@gmail.com

\begin{abstract}
ABSTRAK
Penelitian ini bertujuan untuk mengetahui tingkat pencemaran $\mathrm{Pb}$ dan $\mathrm{Cd}$ yang terjadi di perairan Teluk Semarang. Penelitian dilakukan di 2 (dua) stasiun penelitian berbeda yaitu perairan Tambak Lorok (stasiun I) dan perairan Mangunhardjo (stasiun II). Analisa kandungan logam berat pada sedimen dilakukan dengan menggunakan AAS. Perhitungan kandungan bahan organik dilakukan dengan metode Gravimetri. Perhitungan kandungan karbon organik dilakukan dengan mengonversi dari kandungan bahan organik. Karbon merupakan unsur yang dapat mengikat unsur-unsur lain di perairan. Proses identifikasi makrozoobentos dilakukan dengan metode check list. Rata-rata konsentrasi logam berat $\mathrm{Pb}$ dan $\mathrm{Cd}$ yang didapatkan di stasiun I sebesar 15,709 $\mathrm{mg} / \mathrm{kg}$ dan $<0,004 \mathrm{mg} / \mathrm{kg}$, sedangkan rata-rata konsentrasi logam berat $\mathrm{Pb}$ dan $\mathrm{Cd}$ di stasiun II sebesar 12,283 $\mathrm{mg} / \mathrm{kg}$ dan $<0,004 \mathrm{mg} / \mathrm{kg}$. Famili makrozoobentos tertinggi yang didapatkan pada kedua stasiun adalah famili Archidae dan Nereidae. Analisa makrozoobentos menghasilkan nilai keanekaragaman pada stasiun I sebesar 1.3008 dan pada stasiun II sebesar 1.00424; nilai keseragaman pada stasiun I sebesar 0.80823 dan pada stasiun II sebesar 0.9141; dan nilai dominasi pada stasiun I sebesar 0.32426 dan pada stasiun II 0.38776 . Nilai korelasi antara logam berat dengan karbon organik sebesar 0,632, logam berat dengan kelimpahan makrozoobentos sebesar 0,591, dan karbon organik dengan kelimpahan makrozoobentos sebesar 0,496. Nilai korelasi tersebut menunjukkan bahwa adanya hubungan yang cukup kuat antar ketiga variabel tersebut. Nilai keseragaman makrozoobentos mendekati 1 yang menunjukkan spesies cukup beragam dan tidak terjadi dominasi di kedua stasiun. Nilai keanekaragaman makrozoobentos pada kedua stasiun berada pada nilai $1>\mathrm{a}<3$ yang menunjukkan bahwa terjadi pencemaran sedang pada kedua perairan tersebut.
\end{abstract}

Kata Kunci : Timbal; Kadmium; Kelimpahan makrozoobentos; Teluk Semarang.

\begin{abstract}
This research supposed to know the level of $\mathrm{Pb}$ and $\mathrm{Cd}$ pollution that occurred in Semarang Bay waters. The research was conducted in 2 (two) different research stations that were in Tambak Lorok (station I) and Mangunhardjo (station II) waters. Analysis of heavy metals in organic contents used AAS. Calculated the organic matter contents used Gravimetri method. Calculated the organic carbon with covertion from organic matter contents. Carbon is an element that can bind other elements in the water. Macrozoobenthos identify processed used check list method. The average concentration of heavy metal of Pb and Cd from station I 15,709 $\mathrm{mg} / \mathrm{kg}$ and $<0,004 \mathrm{mg} / \mathrm{kg}$, and average of heavy metal concentration of Pb and Cd from station II $12,283 \mathrm{mg} / \mathrm{kg}$ and $<0,004 \mathrm{mg} / \mathrm{kg}$. Macrozoobentos analysis resulted value of diversity in station I was 1.3008 and in station II was 1.00424; uniformity value in station I was 0.80823 and value from station II was 0.9141; and dominance value from ststion I was 0.32436 and value of dominance from station II was 0.38776 . Correlation value between heavy metal and organic carbon is 0,632, heavy metal and macrozoobenthos abundance is 0,591, and organic carbon and macrozoobenthos abundance is 0,496. Those correlation value indicated that there is a relation between the three variables. Uniformity value approached to one (1) that means existence of species good enough diverse and that mean there was no domination in those two (2) stations, and macrozoobenthos diversity's value in the two (2) stations was $1>a<3$ that mean there was indicated moderate pollution in both of research station.
\end{abstract}

Key Words : Lead; Cadmium; Abundance of macrozoobentos; Semarang bays.

*) Penulis penanggungjawab

${ }^{\odot}$ Copyright by Management of Aquatic Resources (MAQUARES) 


\section{PENDAHULUAN}

Teluk Semarang merupakan perairan yang sangat banyak aktifitas manusia, baik itu kegiatan penangkapan perikanan, budidaya keramba, pelabuhan niaga, industri, dan pembangkit listrik. Kegiatan-kegiatan menghasilkan limbah baik cair, padat, dan gas ataupun organik dan limbah berbahaya beracun. Limbah tersebut mengakibatkan perairan ini banyak mengandung bahan organik dan juga logam berat seperti timbal $(\mathrm{Pb})$ dan cadmium (Cd) dari hasil kegiatan industri. Menurut Dinas Kelautan dan Perikanan Provinsi Jawa Tengah (2011) dalam Adinugroho et al. (2014), Teluk Semarang merupakan kawasan pesisir yang telah menjadi kawasan vital bagi pertumbuhan ekonomi terutama di Kota Semarang. Hal tersebut ditunjukkan dengan banyaknya fasilitasfasilitas niaga diantaranya pelabuhan niaga Tanjung Mas, Kawasan industri Terboyo, Bandar udara Ahmad Yani, PLTU dan PLTG Tambak Lorok (PT Indonesia Power).

Perairan Tambak Lorok dan Mangunharjo merupakan perairan yang terletak di sepanjang Teluk Semarang. Perairan Tambak Lorok mempunyai aktifitas yang tinggi karena disana banyak terdapat aktifitas industri, dan aliran sungai Banjir Kanal Timur yang merupakan aliran sungai besar yang membelah Kota Semarang. Perairan Mangunharjo merupakan perairan di Kota Semarang yang berbatasan dengan Kabupaten Kendal, di sekitar perairan mangunharjo banyak terdapat industri-industri pengolahan hasil perikanan yang berskala rumah tangga.

Bentos merupakan organisme yang hidup di permukaan atau di dalam substrat dasar perairan yang meliputi tumbuhan (fitobentos) dan hewan (zoobentos). Diantara zoobentos yang relatif lebih mudah untuk diidentifikasi dan peka terhadap perubahan lingkungan perairan adalah kelompok invertebrata makro atau lebih dikenal dengan makrozoobentos. Makrozoobentos memiliki ukuran lebih dari $1 \mathrm{~mm}$ dan dapat mencapai ukuran tubuh setidaknya 3-5 mm saat pertumbuhan maksimalnya. Makrozoobentos memiliki peranan yang sangat penting dalam siklus nutrien di dasar perairan diantaranya sebagai mata rantai penghubung dalam aliran energi dan siklus alga planktonik sampai konsumen tingkat tinggi. (Suartini et al., 2007).

Timbal $(\mathrm{Pb})$ dianggap sebagai senyawa beracun (toksikan) yang utama terhadap beberapa organisme perairan serta merupakan racun nonspesifik yang mempengaruhi secara luas sistem fisiologi pada organisme. Kadar Timbal di perairan cenderung selalu meningkat karena penggunaannya oleh kegiatan manusia seperti penambangan, peleburan, pembersihan dan berbagai penggunaan lainnya. (Kencono, 2006).

Menurut Effendi (2003), timbal ( $\mathrm{Pb}$ ) di perairan ditemukan dalam bentuk terlarut dan teruspensi. Kadar dan toksisitas timbal dipengaruhi oleh kesadahan, $\mathrm{pH}$, alkalinitas, dan kadar oksigen. Timbal membentuk senyawa kompleks yang memiliki sifat kelarutan rendah di perairan. Akumulasi timbal dalam tubuh manusia dapat mengakibatkan gangguan pada otak dan ginjal, serta kemunduran mental pada anak yang sedang tumbuh. Kelarutan timbal pada perairan lunak (soft water) sekitar $0,5 \mathrm{mg} /$ liter, sedangkan pada perairan sadah (hard water) sekitar $0,003 \mathrm{mg} / \mathrm{liter}$.

Menurut Fitriawan (2010), kadmium (Cd) yang terkonsentrasi dan terpapar ke biota perairan lambat laun akan mengkibatkan terjadinya gangguan-gangguan yang memungkinkan mengubah struktur anatomi biota tersebut, misalnya terjadinya perubahan sistem metabolisme, sistem respirasi, dan sistem sekresi. Karena logam kadmium dapat menyumbat insang dan sistem pernafasan serta menghambat sistem kerja ginjal pada biota yang terakumulasi.

Kadmium juga bersifat kumulatif dan sangat toksik bagi manusia karena dapat mengganggu fungsi ginjal dan paru-paru, meningkatkan tekanan darah, dan mengakibatkan kemandulan pada pria dewasa. Kadmium dapat terakumulasi pada organisme dan bersifat sangat toksik. Kesadahan dan $\mathrm{pH}$ dapat mempengaruhi toksisitas kadmium. Kadmium banyak digunakan oleh industri metalurgi, pelapisan logam, pigmen, baterai, peralatan elektronik, pelumas, peralatan fotografi, gelas, keramik, tekstil, dan plastik (Effendi, 2003).

Unsur logam di perairan merupakan unsur bebas yang dapat diikat dengan unsur karbon. Untuk mengetahui unsur karbon yang terkandung dalam sedimen didapatkan dari mengonversi kandungan bahan organiknya. Menurut Aishah et al. (2015), karbon organik total menyediakan informasi mengenai semua subtansi organik yang terkandung dalam air atau sedimen. Determinasi dari karbon organik sangat penting untuk diketahui dalam upaya mengidentifikasi persentase substansi organik dalam sedimen, dan zat polusi yang memasuki sungai dan mengendap. Zat-zat polusi yang yang biasanya memasuki perairan sungai dan membawa banyak kandungan karbon didalamnya diantaranya adalah pestisida, pelarut, minyak mineral, asam humat, dan senyawa organik yang terklorinasi.

Menurut Darmono (1995) dalam Sawestri (2006), dalam pemantauan pencemaran logam di perairan, peran analisis biota air sangat penting dibandingkan dengan analisis fisika-kimia perairan. Hal ini dikarenakan kandungan logam dalam air selalu berubah-ubah bergantung dari keadaan lingkungan dan iklim, sebaliknya dengan menggunakan indikator biologi seperti makrozoobentos dapat dimanfaatkan sebagai alat pemantau secara kontinyu.

Perubahan kualitas ekosistem pada perairan Tambak Lorok dan Mangunharjo akan mempengaruhi perubahan kondisi biologis dan struktur komunitas dari organisme makrozoobentos yang mendiaminya. Ada berbagai macam cara untuk mengindikasi suatu perairan tercemar atau tidak tercemar, diantaranya adalah dengan melihat dari struktur komunitas makrozoobentos. Makrozoobentos merupakan salah biota dasar perairan yang hidupnya di substrat perairan, Makrozoobentos merupakan salah satu biota yang umum untuk digunakan 
sebagai indikator pencemaran perairan karena makrozoobentos tidak memiliki mobilitas yang tinggi dan rentan terhadap perubahan-perubahan lingkungan perairan misalnya pencemaran.

\section{METODE PENELITIAN}

Lokasi sampling penelitian dilakukan di 2 (dua) lokasi perairan yang berbeda, yaitu: stasiun I berada di perairan Tambak Lorok dan stasiun II berada di periaran Mangunharjo. Masing-masing stasiun terdiri dari 5 titik pengambilan sampel penelitian. Penentuan lokasi sampling dengan menggunakan metode purposive random sampling yaitu teknik penentuan lokasi sampling secara acak namun tetap dengan pertimbangan-pertimbangan khusus sehingga layak untuk dijadikan lokasi penelitian. Peta stasiun pengambilan sampel disajikan pada Gambar 1 dan Gambar 2.

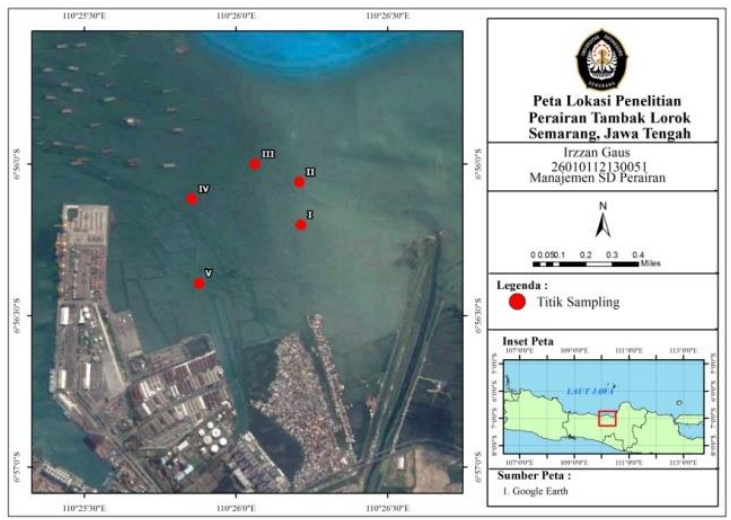

Gambar 1. Lokasi titik sampling pada stasiun 1

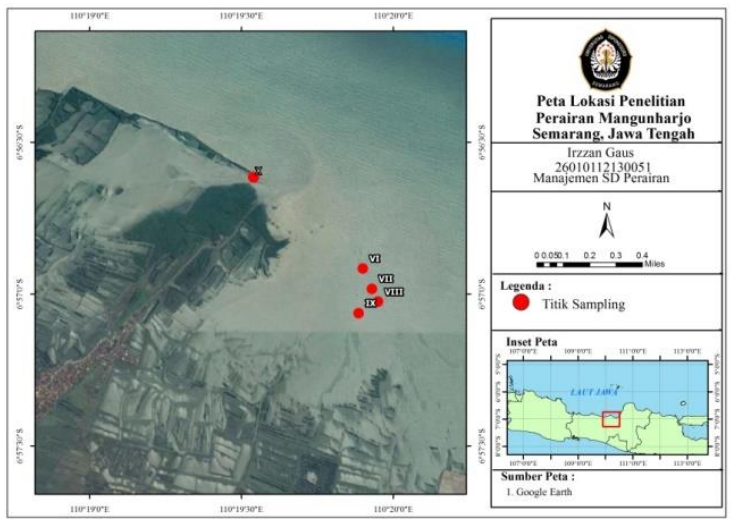

Gambar 2. Lokasi titik sampling pada stasiun 2

\section{Pengambilan Sampel Tanah}

Langkah-langkah pengambilan sampel tanah yaitu menentukan titik pada setiap staisun. Selanjutnya pengambilan tanah menggunakan sedimen grab dan kemudian sampel disimpan dalam plastik sampel untuk diuji di laboratorium.

\section{Analisa Sedimen}

1. Analisis kandungan logam berat

Analisis kandungan logam dalam sedimen sampel penelitian dilakukan di Balai Besar Teknologi Pencegahan Pencemaran Industri (BBTPPI) Semarang dengan menggunakan metode sebagai berikut:

- Sampel dicampurkan sampai homogen. Untuk setiap prosedur destruksi, sampel ditimbang 1-4 gram (berat basah) atau 1 gram (berat kering) dengan ketelitian sampai 0,01 gram kemudian sampel dimasukkan dalam labu destruksi. Sampel dengan kandungan air tinggi dipakai sampel dengan ukuran yang lebih besar sepanjang destruksinya bisa dilakukan dengan sempurna.

- Sampel didestruksi untuk kemudian dianalisis dengan GFAA, pertama sampel sedimen dimasukkan ke dalam labu lalu sampel ditambahkan dengan $10 \mathrm{ml}$ 1:1 $\mathrm{HNO}_{3}$, selanjutnya aduk sampel dan tutup labu dengan pendingin refluks. Selanjutnya sampel dipanaskan hingga $95^{\circ} \mathrm{C} \pm 10-15$ menit lalu sampel didinginkan. Setelah itu, sampel ditambahkan dengan $5 \mathrm{ml} \mathrm{HNO}$ pekat, selanjutnya sampel direfluks kembali selama 30 menit (jika timbul uap berwarna coklat menandakan bahwa $\mathrm{HNO}_{3}$ sedang mengoksidasi sampel). Selanjutnya sampel ditambahkan kembali dengan $\mathrm{HNO}_{3}$ sampai tidak ada uap coklat yang memandakan bahwa reaksi telah sempurna. Selanjutnya sampel kembali dipanaskan pada temperatur $95^{\circ} \mathrm{C}$ $\pm 5^{\circ} \mathrm{C}$ selama $2 \mathrm{jam}$. Setelah sampel mendingin, sampel ditambahkan dengan $2 \mathrm{ml}$ air dan $3 \mathrm{ml} \mathrm{H}_{2} \mathrm{O}_{2} 30 \%$. Selanjutnya sampel ditutup kembali dengan pendingin refluks agar peroksida bereaksi. Selanjutnya pemanasan destruksi peroksida dilakukan sampai volume akhir $5 \mathrm{ml}$, atau sampel dipanaskan pada temperatur $95^{\circ} \mathrm{C} \pm 5^{\circ} \mathrm{C}$ selama 2 jam. Kemudian sampel yang telah didestruksi asam peroksida tersebut ditambahkan dengan $10 \mathrm{ml}$ HCI pekat, lalu sampel ditutup dengan pendingin refluks dan sampel dipanaskan pada temperatur $95^{\circ} \mathrm{C} \pm 5^{\circ} \mathrm{C}$ selama 15 menit. Selanjutnya sampel disaring dengan kertas saring Whatman 41 atau setara, lalu filtrat tersebut dimasukkan ke dalam labu ukur dan ditambahkan dengan air hingga $100 \mathrm{ml}$. Selanjutnya sampel dianalisa dengan FLAA.

- Perhitungan kadar air dilakukan dengan cara menimbang berat sampel, kemudian sampel dipanaskan di dalam oven dengan temperatur $100^{\circ} \mathrm{C}$ selama 3 jam. Selanjutnya setelah sampel mendingin, sampel ditimbang kembali. Kemudian sampel kembali dipanaskan di dalam oven dengan temperatur $100^{\circ} \mathrm{C}$ selama 1 jam. Setelah sampel mendingin, sampel ditimbang kembali, kemudian hitung kadar air pada sampel.

- Perhitungan kadar kepadatan menggunakan rumus:

$$
\mathrm{W}=\frac{C \text { aas }}{w} \times V \times P \times 100 \%
$$

\footnotetext{
${ }^{\circledR}$ Copyright by Management of Aquatic Resources (MAQUARES)
} 
Dimana :

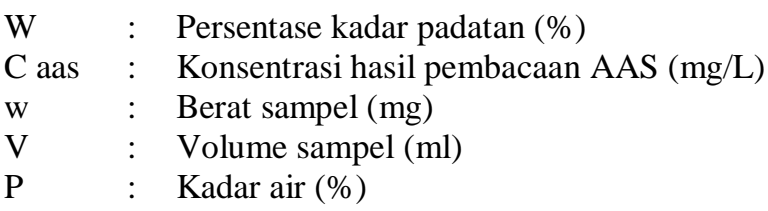

2. Bahan organik dan karbon organik

Analisa bahan organik pada sedimen menggunakan prinsip Gravimetrik. Langkah-langkah perhitungan berat bahan organik pada sedimen adalah dengan cara mengoven 20 gram sampel sedimen dari masing-masing titik setiap stasiun penelitian dengan suhu $60^{\circ} \mathrm{C}$ selama 24 jam hingga kering dan dapat digerus, kemudian sampel sedimen digerus menggunakan porcelain grinder dan setelah digerus dioven kembali hingga kering sempurna. Setelah itu timbang 5 gram sampel kemudian sampel dibakar menggunakan alat pengabuan (furnace) dengan temperatur mencapai $550^{\circ} \mathrm{C}$ selama 4 jam. Setelah dibakar, sampel ditimbang kembali. Selisih antara berat sebelum dan setelah dibakar dianggap sebagai berat bahan organik (Pamuji, 2015). Menurut Sudjadi et al. (1971), untuk menghitung jumlah karbon organik yang terkandung di dalam sampel dihitung dengan cara mengonversi dari jumlah kandungan bahan organik yang terkandung di dalam sampel menggunakan rumus berikut:

$$
\text { Corg }(\%)=\frac{B O(\%)}{1,724}
$$

\section{Analisa makrozoobentos}

Sampling makrozoobentos dilakukan dengan menggunakan Ekman grab untuk mengambil sedimen. Kemudian makrozoobentos dipisahkan dari sedimen. Untuk mengidentifikasi makrozoobentos dilakukan dengan metode check list menggunakan buku identifikasi FAO (2002). Identifikasi makrozoobentos dilakukan dengan cara mencocokkan sampel makrozoobentos dengan gambar yang terdapat pada buku identifikasi makrozoobentos. Perhitungan kelimpahan, keanekaragaman, keseragaman, dan dominasi dilakukan dengan menggunakan rumus sebagai berikut:

- Kelimpahan individu

Kelimpahan makrozoobentos dihitung dengan menggunakan rumus sebagai berikut (Odum, 1994):

$$
K I=a \times n i
$$

Dimana :

$\mathrm{KI}=$ Kelimpahan individu (ind $/ \mathrm{m}^{3}$ )

a = bilangan konversi ( $1 /$ volume total)

$\mathrm{ni}=$ Jumlah individu spesies $-\mathrm{i}$

- Indeks Keanekaragaman

Indeks keanekaragaman (H') dihitung dengan menggunakan formulasi Shannon-Wiener (Odum, 1994):

$$
H^{\prime}=-\sum_{i=1}^{s} P i \ln P i
$$

Dimana :

H' = Indeks keanekaragaman

pi $=$ Peluang spesies I dari total individu $(\mathrm{ni} / \mathrm{N})$

ni = Jumlah spesies $\mathrm{i}$

$\mathrm{N}=$ Jumlah total individu

- Indeks Keseragaman

Indeks keseragaman digunakan untuk melihat nilai penyebaran jumlah individu spesies pada tingkat komunitas, untuk menghitung nilai indeks keseragaman ini menggunakan rumus berikut (Odum, 1994):

Dimana :

$$
e=\frac{H^{\prime}}{H \max }
$$

e $\quad=$ Indeks keseragaman

H' = Indeks keanekaragaman

$\mathrm{H} \max =\ln \mathrm{s}$, dimana s adalah banyaknya spesies

- Indeks dominansi (D)

Indeks domonansi digunakan untuk mengetahui ada atau tidaknya spesies yang mendominasi. Indeks dominasi dihitung dengan menggunakan rumus indeks dominasi Simpson (Odum, 1994) sebagai berikut:

$$
D=\sum\left(\frac{\mathrm{ni}}{N}\right)^{2}
$$

${ }^{\oplus}$ Copyright by Management of Aquatic Resources (MAQUARES) 
Dimana :

$\mathrm{D}=$ Indeks dominansi $; \mathrm{N}=$ Jumlah total individu $; \mathrm{ni}=$ Jumlah individu tiap jenis

\section{HASIL DAN PEMBAHASAN}

Perairan Tambak Lorok merupakan salah satu perairan yang produktif dan berperan penting di Kota Semarang, karena perairan ini merupakan akhir dari aliran sungai Banjir Kanal Timur (BKT) yang merupakan aliran sungai yang melewati kota Semarang dimana pembuangan limbah-limbah industri baik industri besar maupun industri besar yang dibuang ke sungai BKT ini akan berakhir dan menumpuk di muara sungai di perairan Tambak Lorok. Banyaknya industri-industri tersebut menjadikan perairan tambak lorok selalu menerima asupan limbah-limbah cair yang disinyalir mengandung bahan organik tinggi dan logam berat. Hal ini diperkuat oleh Maharani (2016), sungai Banjir Kanal Timur (BKT) merupakan salah satu sistem drainase Kota Semarang dengan pemukiman penduduk yang mengelilinginya yang mengalir ke perairan pesisir Semarang Timur. Sungai ini merupakan jalur dari pembuangan segala limbah dari aktifitas rumah tangga (domestik), industri rumahan, hingga industri besar.

Sedangkan kondisi ekologi di perairan Mangunharjo sangat berbeda dengan kondisi perairan Tambak Lorok, karena di perairan Mangunharjo ini tidak terdapat pembangkit listrik maupun akhir dari aliran sungai besar seperti sungai Banjir Kanal Timur (BKT) yang bermuara di perairan Tambak Lorok. Namun, di perairan mangunharjo ini masihlah dekat dengan kawasan industri, dekat dengan kawasan hutan bakau, dan dialiri aliran sungai-sungai kecil yang mana di aliran sungai ini banyak terdepat industri-industri rumahan pengasapan ikan, industri pengolahan rajungan dan lain-lain. Perairan Mangunharjo juga memiliki arus sangat besar den cepat, hal ini disebabkan perairan di sekitar ini merupakan wilayah yang sangat terbuka.

Hasil yang didapatkan dari pengujian logam berat timbal $(\mathrm{Pb})$ dan kadmium $(\mathrm{Cd})$ pada kedua stasiun penelitian disajikan pada Tabel 1 .

Tabel 1. Hasil uji logam berat

\begin{tabular}{cccc}
\hline St & Titik sampling & $\mathrm{Pb}(\mathrm{mg} / \mathrm{kg})$ & $\begin{array}{c}\mathrm{Cd} \\
(\mathrm{mg} / \mathrm{kg})\end{array}$ \\
\hline & I & 14.90 & $<0.004$ \\
II & 17.75 & $<0.004$ \\
III & 17.26 & $<0.004$ \\
IV & 11.39 & $<0.004$ \\
V & VI & 17.24 & $<0.004$ \\
\hline & VII & 6.256 & $<0.004$ \\
& VIII & 8.665 & $<0.004$ \\
& IX & 8.588 & $<0.004$ \\
& X & 30.56 & $<0.004$ \\
& & 7.348 & $<0.004$
\end{tabular}

Berdasarkan hasil uji logam berat dalam sedimen pada Tabel 1 menunjukkan bahwa kandungan logam berat Kadmium $(\mathrm{Cd})$ di sejumlah titik sampling penelitian masih sangat sedikit jumlahnya yaitu kurang dari $0,004 \mathrm{mg} / \mathrm{Kg}$. Sedangkan kandungan logam berat Timbal $(\mathrm{Pb})$ tertinggi berada pada stasiun II titik 9 sejumlah $30,56 \mathrm{mg} / \mathrm{Kg}$ dan kandungan logam berat Timbal $(\mathrm{Pb})$ terendah terdapat di stasiun II titik 6 sejumlah 6,256 $\mathrm{mg} / \mathrm{Kg}$. Hasil yang didapatkan dari perhitungan kandungan bahan organik (BO) dan karbon organik (C org) disajikan pada Tabel 2.

Tabel 2. Hasil kandungan bahan organik dan karbon organik.

\begin{tabular}{cccc}
\hline \multirow{2}{*}{ St } & \multirow{2}{*}{ Titik sampling } & \multicolumn{2}{c}{ Hasil } \\
\cline { 3 - 4 } & & BO $(\%)$ & C org \\
\hline \multirow{3}{*}{1} & II & 11 & 6.381 \\
& III & 10,38 & 6.021 \\
& IV & 10,06 & 5.835 \\
& V & 7,28 & 4.223 \\
& VI & 11,16 & 6.473 \\
\hline \multirow{2}{*}{2} & VII & 11,44 & 6.636 \\
& VIII & 6,76 & 3.921 \\
& IX & 8,84 & 5.128 \\
& X & 12,4 & 7.193 \\
\end{tabular}

${ }^{\circledR}$ Copyright by Management of Aquatic Resources (MAQUARES) 
Berdasarkan hasil uji bahan organik diatas, dapat diketahui bahwa jumlah kandungan bahan organik tertinggi berada pada Stasiun II titik 9 sejumlah 1,595\% dalam 5 gram sampel sedimen, sedangkan kandungan bahan organik terendah berada pada stasiun yang sama yaitu Stasiun II titik 6 sejumlah $0,931 \%$ dalam 5 gram sampel sedimen. Rata-rata persentase kandungan bahan organik yang terkandung dalam sedimen di Stasiun I dan Stasiun II adalah sebesar $11 \%$ dan 7,98\%. Hal ini menunjukkan bahwa kandungan bahan organik dalam sedimen yang terdapat pada Stasiun I lebih tinggi bila dibandingkan dengan kandungan bahan organik yang terkandung dalam sedimen pada stasiun II. Hasil perhitungan kelimpahan individu makrozoobentos pada masing-masing stasiun penelitian disajikan pada Tabel 3 .

Tabel 3. Kelimpahan individu makrozoobentos

\begin{tabular}{cccccccccccc}
\hline \multirow{2}{*}{ Family } & \multicolumn{9}{c}{ Stasiun 1 } & \multicolumn{7}{c}{ Stasiun 2 } & \multirow{2}{*}{} \\
\cline { 2 - 9 } & I & II & III & IV & V & VI & VII & VIII & IX & X & \\
\hline Polychaeta & & & & & & & & & & & \\
Nereidae & 2 & 1 & 1 & - & - & - & 1 & 1 & 1 & - & 7 \\
Eunicidae & 1 & 1 & 1 & - & 1 & - & - & - & - & - & 4 \\
Sabellidae & - & - & - & - & 1 & - & - & - & - & - & 1 \\
Bivalvia & & & & & & & & & & & \\
Archidae & - & 3 & 2 & 2 & 3 & 1 & - & - & 2 & - & 13 \\
Solenidae & - & 1 & - & - & - & - & - & - & - & - & 1 \\
Veneridae & - & - & - & - & - & - & - & - & - & 1 & 1 \\
\hline
\end{tabular}

Berdasarkan hasil identifikasi makrozoobentos pada Tabel 3, jumlah spesies makrozoobentos lebih banyak dan lebih beragam didapatkan pada stasiun I dibandingkan dengan stasiun II. Jumlah spesies yang sering ditemukan adalah genus Archidae sebanyak 13 ekor dari 10 titik sampling penelitian, sedangkan spesies yang jarang ditemukan adalah spesies dari Sabellidae, Solen, dan Venerupis yang dari kedua stasiun hanya mendapatkan 1 ekor saja. Selanjutnya didapatkan juga hasil perhitungan indeks keanekaragaman (H'), indeks keseragaman (e), dan indeks dominasi (D) makrozoobentos di lokasi penelitian sebagai berikut:

Tabel 4. Indeks Keanekaragaman, Keseragaman, dan Dominasi.

\begin{tabular}{cccc}
\hline \multirow{2}{*}{ St } & Keanekaragaman & Keseragaman & Dominasi \\
\cline { 2 - 4 } & $\mathrm{H}^{\prime}$ & $\mathrm{e}$ & $\mathrm{D}$ \\
\hline $\mathrm{I}$ & 1.300 & 0.808 & 0.324 \\
$\mathrm{II}$ & 1.004 & 0.914 & 0.388 \\
\hline
\end{tabular}

Berdasarkan hasil perhitungan indeks keanekaragaman pada Tabel 4 dapat diketahui bahwa pada kedua stasiun penelitian nilai indeks keanekaragaman lebih dari 1 dan kurang dari 3 yang artinya stabilitas komunitas biota sedang atau tercemar sedang. Sedangkan hasil indeks keseragaman yang mendekati 1 menunjukkan kemerataan antar spesies relatif merata. Dan dari nilai indeks dominasi disimpulkan bahwa tidak terdapat genus yang mendominasi akibat tekenan ekologi karena nilai indeks dominasinya berada diantara $0-1$.

\section{a. Hubungan antara logam berat dan karbon organik (C org)}

Analisis data yang digunakan adalah Korelasi Pearson. Korelasi Pearson ini digunakan untuk mengetahui berapa besar signifikasi antara analisa uji yang diteliti. Menurut Uyanto (2009), uji korelasi yaitu metode statistik yang digunakan untuk melihat hubungan suatu variable terikat atau prediktor (depanden) berdasarkan nilai variabel bebas atau variabel respon (independen). Perhitungan uji statistik dapat menunjukkan nilai $r$ negatif (-) yang berarti korelasi berbanding terbalik antara kedua variabel dan nilai $r$ positif $(+)$ yang berarti terdapat korelasi positif atau berbanding lurus antara kedua variabel. Analisa yang diuji adalah kadar loga berat $(\mathrm{Pb})$ dengan kelimpahan individu makrozoobentos. Analisa uji ini dimaksudkan untuk melihat hubungan antara logam berat timbal $(\mathrm{Pb})$ dengan $\mathrm{C}$ organik di masing-masing titik penelitian. Hasil signifikasi uji Korelasi Pearson ini dapat dilihat pada Tabel 5.

Tabel 5. Korelasi pearson logam berat dengan karbon organik.

\begin{tabular}{llll}
\hline & \multicolumn{1}{c}{$\mathrm{Pb}$} & $\mathrm{Cd}$ \\
\hline \multirow{4}{*}{ C org } & Pearson Correlation & $.632^{*}$ &. \\
& Sig. (2-tailed) & .050 &. \\
& $\mathrm{~N}$ & 10 & 10 \\
\hline
\end{tabular}

*) korelasi cukup

Perhitungan korelasi pada Tabel 5 menyatakan bahwa korelasi yang terjadi antara logam berat timbal $(\mathrm{Pb})$ dengan karbon organik ( $\mathrm{C}$ org) menunjukkan hubungan yang nyata antara keduanya, karena dapat dilihat nilai korelasinya sebesar 0.632 dengan nilai signifikasi 0.05 . Sedangkan untuk korelasi antara kadmium dengan karbon organik tidak dapat dihitung dikarenakan nilai variabelnya yang konstan di semua titik penelitian.

\footnotetext{
${ }^{\circledR}$ Copyright by Management of Aquatic Resources (MAQUARES)
} 


\section{b. Hubungan logam berat dengan kelimpahan makrozoobentos.}

Korelasi pearson antara logam berat timbal dengan kelimpahan makrozoobentos dari semua titik didapatkan hasil pada Tabel 6.

Tabel 6. Korelasi pearson logam berat dengan kelimpahan makrozoobentos.

\begin{tabular}{|c|c|c|}
\hline & & $\mathrm{KI}$ \\
\hline \multirow{3}{*}{ PB } & Pearson correlation & $.591 *$ \\
\hline & Sig. (2-tailed) & .072 \\
\hline & $\mathrm{N}$ & 10 \\
\hline \multirow{3}{*}{$\mathrm{Cd}$} & Pearson correlation & r. \\
\hline & Sig. (2-tailed) & . \\
\hline & $\mathrm{N}$ & 10 \\
\hline
\end{tabular}

*) korelasi cukup.

Berdasarkan Tabel 6 diatas dapat diketahui bahwa ada keterkaitan antara kedua variabel diatas. Nilai korelasi pearson menunjukkan bahwa timbal cukup mempengaruhi kelimpahan makrozoobentos namun nilai signifikasinya menyatakan bahwa keduanya tidak bersignifikan. Sedangkan korelasi antara kadmium dengan kelimpahan makrozoobentos tidak dapat diketahui.

\section{c. Hubungan antara karbon organik ( $\mathrm{C}$ org) dengan kelimpahan makrozoobentos}

Uji korelasi pearson antara karbon organik (C org) dengan kelimpahan makrozoobentos dari kedua stasiun penelitian depat dilihat pada Tabel 7.

Tabel 7. Korelasi pearson karbon organik dengan kelimpahan makrozoobentos.

\begin{tabular}{lll}
\hline & & \multicolumn{1}{c}{ KI } \\
\hline \multirow{3}{*}{ C org } & Pearson correlation & $.496^{*}$ \\
& Sig. (2-tailed) & .145 \\
& $\mathrm{~N}$ & 10 \\
\hline
\end{tabular}

*) korelasi cukup.

Berdasarkan hasil korelasi pada Tabel 7 diketahui bahwaterdapat hubungan yang cukup kuat diantara karbon organik dengan kelimpahan makrozoobentos. Kelimpahan makrozoobentos berbanding lurus dengan tingginya kadar karbon organik pada sedimen. Namun, nilai signifikasi diantara keduanya menunjukkan diantara keduanya tidak bersignifikan.

Kualitas perairan di sekitar Kota Semarang pada umumnya sudah melebihi ambang batas kualitas perairan dikarenakan tingginya pertumbuhan industri-industri baik kecil, menengah, hingga besar. Pesatnya pertumbuhan industri ini lah yang menjadikan perairan di sekitar kota semarang ini banyak menampung buangan-buangan limbah dari industri. Kandungan yang terkandung dalam limbah industri ini bermacammacam, diantaranya adalah logam dan bahan organik. Logam bila terus-menerus dibuang ke perairan lambat laun akan mengendap dan terakumulasi kepada biota-biota di sekitar lingkungannya. Apabila biota yang telah terakumulasi tersebut dikonsumsi oleh manusia, maka logam berat yang terakumulasi pada biota tersebut juga akan terakumulasi paada tubuh manusia yang mengonsumsinya dan apabila terkonsumsi secara terus menerus dapat menyebabkan gangguan kesehatan pada tubuh konsumernya.

Perairan Tambak Lorok mengandung unsur logam lebih tinggi bila dibandingkan dengan unsur logam yang terkandung pada perairan Mangunharjo. Hal ini disebabkan oleh aktifitas perindustrian yang terjadi di sekitar perairan Tambak Lorok dangat tinggi bila dibandingkan dengan perairan Mangunharjo. Pada perairan Tambak Lorok banyak terdapat industri-industri besar dan juga tempat bermuara dari aliran sungai Banjir Kanal Timur yang merupakan salah satu aliran sungai yang besar di Kota Semarang.

Menurut Sarjono (2009) dalam Happy et. al. (2012), perindustrian saat ini banyak menggunakan unsur logam dalam produknya, sehingga menghasilkan limbah yang juga membawa unsur logam berat. Limbah-limbah logam inilah yang nantinya akan sedikit demi sedikit bertumpuk dan pada akhirnya jumlahnya melebihi ambang batas. Peristiwa inilah yang biasa kita sebut dengan pencemaran dimana semakin banyak limbah yang masuk dari industri-industri tersebut maka akan semakin besar pula konsentrasi logam yang terakumulasi di perairan hingga melebihi ambang batas keberadaannya terhadap lingkungan perairan.

Logam berat yang tersuspensi di perairan secara terus menerus akan terakumulasi dan akan mengendap di dasar perairan. Lokasi logam yang tersuspensi akan mengendap dipengaruhi oleh arus dan gelombang. Oleh karenanya kebanyakan logam di perairan berada di dasar perairan di sekitar muara sungai dan pinggir laut. Banyaknya logam yang dibuang bersamaan dengan limbah pabrik lamban laun akan mengancam keberadaan populasi ikan karena daerah estuari merupakan daerah dimana ikan biasanya akan memijah dan berkembang biak.

Oleh karenanya, disamping menggunakan uji laboratorium untuk mengukur kadar kandungan logam dan bahan organik dalam sedimen, kita juga memanfaatkan sifat-sifat yang ada pada makrobentos untuk dijadikan 
sebagai indikator biologis dalam menilai dan memantau kondisi lingkungan perairan tertentu. Hal ini diperkuat oleh Darmono (1995) dalam Sawestri (2006), dalam pemantauan pencemaran logam di perairan, peran analisis biota air sangat penting dibandingkan dengan analisis fisika-kimia perairan. Hal ini dikarenakan kandungan logam dalam air selalu berubah-ubah bergantung dari keadaan lingkungan dan iklim, sebaliknya dengan menggunakan indikator biologi seperti makrozoobentos dapat dimanfaatkan sebagai alat pemantau secara kontinyu.

Berdasarkan hasil dari perhitungan korelasi pearson antara logam timbal, karbon organik, dan kelimpahan relatif menunjukkan bahwa adanya suatu hubungan antara ketiganya. Dalam hal ini logam kadmium tidak dimasukkan kedalam perhitungan dikarenakan nilainya yang konstan tidak memungkinkan untuk dilakukan uji korelasi. Hasil perhitungan menunjukkan bahwa diantara ketiga variabel tersebut ada suatu hubungan. Bila kita kaji lebih jauh, unsur karbon yang terkandung dalam bahan organik memiliki kemampuan untuk mengikat unsurunsur lain karena sifat dasar unsur karbon yang dapat berikatan dengan unsur lainnya. Menurut Young (1998) dalam Maslukah (2013), bahan organik merupakan komponen geokimia yang paling penting dalam mengontrol pengikatan logam-logam berat dari sedimen estuari. Hal ini diperkuat juga oleh penelitiannya, hasil penelitian menunjukkan bahwa unsur logam seperti $\mathrm{Pb}, \mathrm{Cd}$, dan $\mathrm{Cu}$ keberadaannya pada sedimen sangat dipengaruhi oleh bahan organik. Logam berat di perairan biasanya membentuk ikatan kompleks dengan ligan organik seperti asam humus. Meskipun faktor-faktor fisika-kimia lainnya dapat juga mempengaruhi keberadaan logam berat dalam sedimen meskipun dalam skala yang kecil.

Perairan pada kedua lokasi penelitian umumnya memiliki kandungan logam timbal $(\mathrm{Pb})$ yang cukup tinggi, terutama pada stasiun I yang bertempat di Tambak Lorok. Kota Semarang terutama di wilayah pesisirnya memang terjadi pertumbuhan industri yang sangat pesat, dan dalam aktifitasnya industri-industri tersebut menghasilkan limbah baik cair, padat, ataupun gas yang mengandung unsur-unsur logam seperti $\mathrm{Pb}, \mathrm{Cd}, \mathrm{Zn}, \mathrm{Cu}$ dan lain sebagainya. Perairan Tambak Lorok mengandung logam pencemar timbal $(\mathrm{Pb})$ yang tinggi, namun tingkat pencemaran terhadap logam kadmium (Cd) rendah. Tingginya logam berat di perairan sangat mempengaruhi biota-biota yang mendiaminya terutama terhadap biota-biota sessile. Menurut Ulfah (2012), makrozoobentos merupakan biota sessile, yaitu biota yang hidup dengan mendiami dasar perairan dengan pergerakan terbatas. Kelimpahan dan keanekaragamannya sangat dipengaruhi oleh perubahan kualitas air dan substrat tempat hidupnya.

Tingginya kandungan bahan organik pada perairan memberikan peluang yang tinggi juga terhadap tingginya kadar logam berat, hal ini dikarenakan unsur karbon (C) yang terkandung di dalam bahan organik tersebut dapat mengikat unsur-unsur bebas lainnya termasuk unsur logam di perairan. Namun, dengan tingginya kandungan bahan organik dalam perairan akan memberikan tempat yang nyaman dan rumah yang kaya akan nutrien untuk kehidupan makrozoobentos di perairan tersebut, sehingga makrozoobentos tersebut dapat hidup dengan baik meskipun dalam perairan tersebut terkandung banyak unsur logam. Menurut Sahidin et al. (2014), kehadiran karbon organik pada sedimen berbanding lurus dengan jumlah bahan organik pada sedimen. Makrozoobentos jenis polychaeta menyukai perairan dengan substrat berlumpur karena mengandung bahan organik dan karbon organik tinggi.

\section{KESIMPULAN}

Perairan Tambak Lorok dan Mangunhardjo terindikasi tercemar sedang karena terkandung banyak unsur logam terutama logam timbal $(\mathrm{Pb})$ di semua titik penelitian dimana berkisar $6.256 \mathrm{mg} / \mathrm{kg}$ hingga $30.56 \mathrm{mg} / \mathrm{kg}$, namun keanekaragaman komunitas makrozoobentos masih cukup stabil dengan nilai indeks keanekaragaman berada pada $1 \leq \mathrm{H}^{\prime} \leq 3$ yang menunjukkan stabilitas komunitas biota sedang dan tercemar sedang.

\section{UCAPAN TERIMAKASIH}

Penulis mengucapkan terimakasih kepada Dr.Ir. Suryanti, M.Pi. dan Arif Rahman, S.Pi.,M.Pi. yang telah membantu penulis dalam memperbaiki isi jurnal ini.

\section{DAFTAR PUSTAKA}

Adinugroho, M., Subiyanto., dan Haeruddin. 2014. Komposisi dan Distribusi Plankton di Perairan Teluk Semarang. Saintifika 16(2) : 39-48.

Aishah, M. A. S., Carolyn P., dan Masni M. A. 2015. Surface Sediment Analysis on Petroleum Hydrocarbon and Total Organic Carbon from Coastal Area of Papar to Tuaran, Sabah. Malaysian Journal of Analytical Sciences vol. 19(2): 318-324.

Effendi, H. 2003. Telaah Kualitas Air bagi Pengelolaan Sumberdaya dan Lingkungan Perairan. Penerbit: Kanisius.

Fitriawan, F. 2010. Analisis Perubahan Mikroanatomi dan Variasi Pola Pita Isozim pada Insang dan Ginjal Kerang Air Tawar Anodonta woodiana terhadap Paparan Logam Berat Kadmium. [Tesis]. Universitas Sebelas Maret. 
Food and Agriculture Organization [FAO]. 2002. The Living Marine Resources of The Western Central Atlantic Volume 1. Departement of Biological Sciences. Old Dominion University, Nolfolk, Virginia, USA. (diedit oleh Kent E. Carpenter).

Happy, A. R., Masyamsir., dan Y. Dhahiyat. 2012. Distribusi Kandungan Logam Berat Pb dan Cd pada Kolom Air dan Sedimen Daerah Aliran Sungai Citarum Hulu, Jurnal Perikanan dan kelautan 3(3): 175-182.

Kencono, L. C. 2006. Pemanfaatan Kerang Hijau (Perna viridisLinn.) sebagai Bioindikator Pencemaran Logam Timbal (Pb) di Perairan Kamal Muara, Teluk Jakarta. [Skripsi]. Institut Pertanian Bogor.

Maslukah, L. 2013. Hubungan antara Konsentrasi Logam Berat $\mathrm{Pb}, \mathrm{Cd}, \mathrm{Cu}, \mathrm{Zn}$, dengan Bahan Organik dan Ukuran Butir dalam Sedimen di Estuari Banjir Kanal Barat, Semarang. Buletin Oseanografi Marina 2: 55-62.

Odum, E. P. 1994. Dasar - Dasar Ekologi Edisi Ketiga. Universitas Gadjah Mada Press. Yogyakarta.

Pamuji, A. 2015. Pengaruh Sedimentasi terhadap Kelimpahan Makrozoobentos di Muara Betahwalang Kabupaten Demak. [Skripsi]. Universitas Diponegoro.

Putri, A. M. S. 2016. Hubungan Tekstur Sedimen dengan Kandungan Bahan Organik dan Kelimpahan Makrozoobentos di Muara Sungai Banjir Kanal Timur Semarang. [Skripsi]. Universitas Diponegoro.

Sahidin, A., Isdradjat, S., Yusli, W. 2014. Struktur Komunitas Makrozoobentos di Perairan Pesisir Tangerang, Banten. Depik 3(3): 226-233.

Sawestri, S. 2006. Kandungan Logam dalam Tubuh Cacing Laut Namalycastis abiuma (Polychaeta: Nereidae) dari Teluk Jakarta. [Skripsi]. Universitas Sebelas Maret.

Suartini, N. M., Sudatri N. W., Pharmawati M., dan A.A.G. Raka Dalem. 2007. Identifikasi Makrozoobentos di Desa Parerenan, Kabupaten Badung, Bali. Ecotrophic 5(1): 41-44.

Sudjadi, M., Widjik, I.M., dan Soleh, M. 1971. Penuntun Analisa Tanah. Bagian Kesuburan Tanah. LPT, Bogor.

Ulfah, Y., Widianingsih., dan M. Zainuri. 2012. Struktur Komunitas Makrozoobenthos di Perairan Wilayah Morosari Desa Bedono Kecamatan Sayung Demak. Jurnal of Marine Research 1(2); 188-196.

Uyanto, S. S. 2009. Pedoman Analisa Data dengan SPSS. Edisi 3. Graha Ilmu. Yogyakarta, hlm. 284. 